ISSN : 2303-1514 | E-ISSN : 2598-5949

\title{
INCREASING STUDENTS' SCIENCE LEARNING OUTCOMES THROUGH DISCOVERY METHOD IN ONLINE LEARNING AT GRADE V OF SD NEGERI 27 PEKANBARU
}

\author{
Rosmidawati Br Sitinjak
}

SD Negeri 27 Pekanbaru, Pekanbaru, Indonesia

rosmidawatisitinjak@gmail.com

\section{PENINGKATAN HASIL BELAJAR IPA MELALUI METODE DISCOVERY DALAM PEMBELAJARAN DARING PADA SISWA KELAS V SD NEGERI 27 PEKANBARU}

\begin{tabular}{|c|c|}
\hline ARTICLE HISTORY & ABSTRACT \\
\hline $\begin{array}{l}\text { Submitted: } \\
\text { 11 Juli } 2021 \\
11^{\text {th }} \text { July } 2021\end{array}$ & $\begin{array}{l}\text { Abstract: This research was motivated by the low science learning outcomes of grade V } \\
\text { students of SD Negeri } 27 \text { Pekanbaru. This was seen from 1) the students' learning outcomes } \\
\text { were not optimal, which was proved by the report card scores, especially in science subjects, } \\
\text { most of the students did not reached the specified minimum completeness criteria (KKM), 2) } \\
\text { students seemed difficult to understand the material presented by the teacher in the classroom } \\
\text { and students rarely answered the questions given by the teacher. This study aimed to improve } \\
\text { students' science learning outcomes at grade of SD Negeri } 27 \text { Pekanbaru. The subjects of this } \\
\text { study were } 30 \text { grade V students of SD Negeri } 27 \text { Pekanbaru. This study was classroom action } \\
\text { research. The research instrument consisted of learning outcomes instruments and data } \\
\text { collection instruments in the form of observation sheets for teacher's activities and students, } \\
\text { activities. Based on the results of the analysis and discussion, it was concluded that the } \\
\text { application of Discovery learning method in online learning improved the students' learning } \\
\text { outcomes in science lessons at grade V of SD Negeri } 27 \text { Pekanbaru. This success was } \\
\text { evidenced by an increase in learning outcomes before taking action in cycle I and cycle II. } \\
\text { Before taking the action, the students' learning outcomes were classified as "Not Good" with a } \\
\text { percentage of } 40 \% \text {. There was an increase in cycle I to } 53.3 \% \text { with the criteria of "Not Good". } \\
\text { Meanwhile, the students' learning outcomes in cycle II also increased to 86.7\% with "Good", } \\
\text { category. This proved that Discovery Learning Method in online learning improved students } \\
\text { science learning outcomes at grade Vof SD Negeri } 27 \text { Pekanbaru. }\end{array}$ \\
\hline
\end{tabular}

\begin{abstract}
Abstrak: Penelitian ini dilatarbelakangi oleh rendahnya hasil belajar IPA siswa kelas V SD Negeri 27 Pekanbaru. Hal ini dapat dilihat dari 1) hasil belajar yang diperoleh siswa belum optimal, hal ini terlihat dari nilai rapor khususnya pada mata pelajaran IPA, sebahagian besar siswa belum mencapai nilai kriteria ketuntasan minimal (KKM) yang ditetapkan, 2) Siswa terkesan sulit memahami materi yang disampaikan oleh guru di kelas dan siswa jarang menjawab pertanyaan yang diberikan oleh gurunya. Penelitian ini bertujuan untuk meningkatkan hasil belajar IPA pada siswa kelas V SD Negeri 27 Pekanbaru. Subjek penelitian ini adalah siswa kelas $V$ SD Negeri 27 Pekanbaru dengan jumlah siswa sebanyak 30 orang. Bentuk penelitian adalah penelitian tindakan kelas. Instrumen penelitian ini terdiri dari instrumen hasil belajar dan instrumen pengumpulan data berupa lembar observasi aktivitas guru dan aktivitas siswa. Berdasarkan hasil analisis dan pembahasan dapat disimpulkan bahwa penerapan metode pembelajaran Discovery dalam pembelajaran daring dapat meningkatkan hasil belajar pada pelajaran IPA siswa kelas V SD Negeri 27 Pekanbaru. Keberhasilan ini dibuktikan dengan adanya peningkatan hasil belajar sebelum dilakukan tindakan ke siklus I dan ke siklus II. Sebelum dilakukan tindakan hasil belajar siswa tergolong "Kurang Baik" dengan persentase 40\%, terjadi peningkatan pada siklus I menjadi 53.3\% dengan kriteria "Kurang Baik". Sedangkan hasil belajar siswa pada siklus II juga terjadi peningkatan mencapai $86.7 \%$ dengan kategori "Baik", hal ini membuktikan bahwa dengan penerapan Metode Pembelajaran Discovery dalam pembelajaran daring dapat meningkatkan hasil belajar IPA siswa kelas V SD Negeri 27 Pekanbaru.
\end{abstract}

Kata Kunci : metode discovery dalam pembelajaran daring, hasil belajar 


\section{CITATION}

Sitinjak, R. B. (2021). Increasing Students' Science Learning Outcomes through Discovery Method in Online Learning at Grade V of SD Negeri 27 Pekanbaru. Primary: Jurnal Pendidikan Guru Sekolah Dasar, 10 (4), 997-1011. DOI: http://dx.doi.org/10.33578/jpfkip.v10i4.8452 .

\section{PENDAHULUAN}

Kegiatan belajar mengajar baik dirumah maupun di sekolah yang dilakukan oleh guru memiliki peran yang sangat penting, sebagaimana guru akan tetap menjadi perannya yakni sebagai mediator, fasilitator, motovator, inovator, dan dinamisator sehingga untuk menjalankan tugasnya dalam proses belajar mengajar diperlukan keterampilan dan kemampuan yang baik (Mulyasa, 2007). Untuk dapat melaksanakan tugas mengajar dengan baik guru harus memiliki kemampuan mangajar yang baik. Terutama pada saat ini dengan adanya wabah covid 19 tentunya guru akan memiliki peran dan tugas yang berat untuk melakukan kegiatan pembelajaran dirumah dengan efektif (Asran, 2021). Efektivitas pembelajaran adalah ukuran keberhasilan dari suatu proses interaksi antara siswa maupun antara siswa dengan guru dalam situasi edukatif untuk mencapai tujuan pembelajaran (Gustiana, 2021). Efektivitas pembelajaran tentunya untuk menyatakan seberapa jauh target (kuantitas, kualitas dan waktu) telah tercapai. Dimana makin besar presentasi target yang dicapai, makin tinggi efektifitasnya. Kegiatan belajar untuk mengatahui tingkat keberhasilan (pemahaman) siswa dalam mencapai tujuan yang di terapkan, maka evaluasi hasil belajar memiliki saran berupa ranah yang terkandung dalam tujuan yang diklafikasikan menjadi macam yakni ranah kognitif, ranah afektif, dan ranah psikomotorik (Purwanto, 2007). Kegiatan belajar mengajar yang dilakukan oleh guru di rumah harus menunjukan efektif dalam penggunaan pembelajaran sistem daring (Sugiarto, 2021).

Efektivitas pembelajaran dengan sistem daring pada saat ini merupakan hal yang harus dicapai dan dilakukan oleh setiap guru, sehingga keefektifan dalam penggunaan daring merupakan sesuatu yang wajid diperoleh dan dilakukan oleh setiap guru, sebab kegiatan pembelajaran memang harus dilakukan dengan sistem daring (Azuar, 2021). Kegiatan pembelajaran daring bukan hanya dilakukan pada saat ini saja, namun sebelumnya dari tahun-tahun sebelumnya sudah di wacanakan suatu metode pembelajaran daring, akan tetapi metode ini belum sepenuhnya dapat dilakukan oleh para guru dikarenakan menyesuaikan materi yang diajarkan (Nur, 2021). Pada kondisi seperti ini semua guru atau tenaga pendidik diharuskan untuk mengganti pembelajaran menggunakan E-learning atau melalui media online. Berbagai platform digunakan untuk melakukan pengajaran sehingga perlu didukung dengan fasilitas pembelajaran yang baik dan pemanfaatan teknologi informasi (Azimah \& Kurniaman, 2019).

IPA merupakan ilmu yang mempelajari tentang makhluk hidup dan proses kehidupan di dalam semesta serta mencari tahu tentang alam secara sistematis. Sehingga IPA bukan hanya penguasaan kumpulan pengetahuan yang berupa fakta, konsep atau prinsip apa saja. Namun juga merupakan suatu proses penemuan. Pendidikan IPA di sekolah dasar diharapkan menjadi wahana bagi siswa untuk mengembangkan kompetensi agar menjelajahi dan memahami alam sekitar, serta untuk menunjukkan kemampuan berpikir, bekerja dan bersikap ilmiah sehingga dapat mengkomunikasikannya sebagai aspek yang penting dalam kehidupan sehari-hari (Slameto, 2003). Kemampuan guru sangat dituntut dalam mengelola kelas agar suasana belajar siswa selalu aktif dan produktif melalui strategi dan model mengajar yang direncanakan (Sardiman, 2008). Mengajar itu sendiri juga merupakan serangkaian peristiwa yang dirancang oleh guru dalam memberi dorongan kepada siswa 
belajar baik yang bersifat individual maupun kelompok (Kurniaman \& Huda, 2018). Rangkaian peristiwa dalam mengajar, sebagai pendorong siswa belajar diterima oleh siswa secara individual pula.

Berdasarkan hasil pengamatan di kelas V SD Negeri 27 Pekanbaru ditemukan beberapa gejala dalam pelajaran IPA yaitu, 1) Hasil belajar yang diperoleh siswa belum optimal, hal ini terlihat dari nilai rapor khususnya pada mata pelajaran IPA, sebahagian besar siswa belum mencapai nilai kriteria ketuntasan minimal (KKM) yang ditetapkan, 2) Siswa terkesan sulit memahami materi yang disampaikan oleh guru di kelas dan siswa jarang menjawab pertanyaan yang diberikan oleh gurunya. Salah satu usaha yang dapat dilakukan adalah menerapkan model pembelajaran yang bertujuan mengaktifkan siswa yaitu supaya siswa mau bertanya tentang materi yang sedang dipelajari terlebih dahulu kepada teman sekelompoknya, bersemangat untuk mengerjakan latihan serta mempunyai rasa tanggung jawab dengan tugas dan kelompoknya. Maka perlu digunakan metode pembelajaran yang dapat meningkatkan aktvitas belajar siswa, seiring dengan meningkatnya aktivitas siswa diharapkan pula meningkatnya hasil belajar siswa.

Metode pembelajaran yaitu metode pembelajaran discovery. Metode pembelajaran discovery adalah cara untuk menyampaikan ide atau gagasan lewat penemuan. Belajar merupakan proses mental dimana siswa mampu mengasimilasikan suatu konsep atau prinsip. Proses mental yang dimaksud adalah mengamati, menggolong-golongkan, membuat dugaan, menjelaskan, mengukur dan membuat kesimpulan. Dalam metode ini siswa dibiarkan menemukan sendiri atau mengalami proses mental itu sendiri, guru hanya membimbing, dan memberikan instruksi. Keuntungan metode pembelajaran dalam pembelajaran IPA yaitu siswa aktif melakukan kegiatan, memberi kesempatan kepada siswa untuk memahami topik kemudian berbagi kepada temannya tentang topik yang dipahaminya, melatih intelektual dan kekompakan siswa.

\section{KAJIAN TEORI}

Metode pembelajaran discovery merupakan model mengajar yang berusaha meletakkan dasar dan mengembangkan cara berpikir ilmiah, siswa betul-betul ditempatkan sebagai subjek yang belajar, peranan guru dalam model pembelajaran discovery adalah pembimbing belajar dan fasilitator belajar. Tugas utama guru adalah memilih masalah yang perlu dilontarkan kepada kelas untuk dipecahkan oleh siswa sendiri. Tugas berikutnya dari guru adalah menyediakan sumber belajar bagi siswa dalam rangka pemecahan masalah. Sudah barang tentu bimbingan dan pengawasan dari guru masih tetap diperlukan, namun campur tangan terhadap kegiatan siswa dalam pemecahan masalah harus dikurangi (Yuliana, 2018).

Metode pembelajaran discovery adalah cara untuk menyampaikan ide atau gagasan lewat penemuan (Roestiyah, 2001). Belajar merupakan proses mental dimana siswa mampu mengasimilasikan suatu konsep atau prinsip. Proses mental yang dimaksud adalah mengamati, menggolong-golongkan, membuat dugaan, menjelaskan, mengukur dan membuat kesimpulan. Dalam teknik ini siswa dibiarkan menemukan sendiri atau mengalami proses mental itu sendiri, guru hanya membimbing dan memberikan instruksi. Kata penemuan sebagai model mengajar merupakan penemuan yang dilakukan oleh siswa, siswa menemukan sendiri sesuatu hal yang baru, ini tidak berarti yang ditemukannya benar-benar baru, sebab sudah diketahui orang lain.

Pengertian discovery learning merupakan metode belajar yang mendorong siswa untuk mengajukan pertanyaan dan menarik kesimpulan dari prinsip-prinsip umum praktis contoh pengalaman. Dan yang menjadi dasar ide J. Bruner ialah pendapat dari Piaget yang menyatakan bahwa anak harus berperan secara aktif didalam belajar di kelas. Untuk itu Bruner memakai cara dengan apa yang 
disebutnya discovery learning, yaitu dimana siswa mengorganisasikan bahan yang dipelajari dengan suatu bentuk akhir (Dimyati dan Mudjiono, 2008).

Pembelajaran penemuan merupakan salah satu model pembelajaran yang digunakan dalam pendekatan konstruktivis modern. Pada pembelajaran penemuan, siswa didorong untuk terutama belajar sendiri melalui keterlibatan aktif dengan konsep-konsep dan prinsipprinsip. Guru mendorong siswa agar mempunyai pengalaman dan melakukan eksperimen dengan memungkinkan mereka menemukan prinsip-prinsip atau konsepkonsep bagi diri mereka sendiri. Pembelajaran discovery adalah model pembelajaran yang mengatur sedemikian rupa sehingga anak memperoleh pengetahuan yang belum diketahuinya itu tidak melalui pemberitahuan, sebagian atau seluruhnya ditemukan sendiri (Syah, 2007).

Pembelajaran daring dilakukan dengan menggunakan model sebagai aplikasi learning management system yang menyediakan fiturfitur kegiatan pembelajaran kooperatif dan kolaboratif untuk para tutor dimana fitur ini diplih sendiri oleh tutor untuk melaksanakan pengajaran secara daring (Dewi, 2007). Pembelajaran daring merupakan suatu bentuk pembelajaran yang dilakukan oleh guru kepada siswa dalam system online tanpa tatap muka sehingga guru akan menuntun setiap siswa dalam melakukan kegiatan pembelajaran kemudian akan terlaksana kegiatan sesuai dengan arahan.

Pembelajaran daring merupakan model pembelajaran yang berbasis ICT. Daya dukung program ini adalah fasilitas ICT berupa Web LMS, program monitoring, modular, dan suplemen dalam bentuk multimedia (Dewi, 2007). Pembelajaran dengan menggunakan media daring (online) berbasis Web memberikan pengaruh positif dalam peningkatkan proses pemeblajaran. Pengaruh positif ini bukan hanya diperoleh siswa melalui hasil belajarnya malainkan juga kepada guru (Ro'ifah, Pratiwi, \& Ismaya,
2021). Menurut beberapa hasil penelitian menyebutkan bahwa melalui pembelajaran dari berbasis web siswa merasa puas, karena materi yang disampaikan telah diorganisasikan dengan baik. Melalui pembelajaran daring menjadi lebih fleksibel dan membantu mengakomodasi berbagai kebutuhan gaya belajar serta menumbuhkan rasa percaya dalam belajar. Selain itu melalui pembelajaran daring dapat membantu siswa memecahkan masalah yang diangkat dalam proses pembelajaran sehingga akan tercipta pembelajaran yang efektif, efisien dan objektif baik secara individu maupun berkelompok.

Berdasarkan beberapa pendapat para ahli di atas dan beberapa jurnal penelitian melalui hasil penelitiannya maka dapat disimpulkan pembelajaran daring adalah bentuk kegiatan pembelajaran yang dilakukan dengan tidak bertatap muka secara langsung antara siswa dan guru, namun secara online, dan dalam pelaksanaanya dapat dilakukan dengan istem kelompok atau individu dalam beberapa materi dibahas serta dapat mengirimkan tugas-tugas dan pertanyaan siswa kepada guru. Sehingga hasil dari kegiatan pembelajaran daring akan membuat siswa lebih merasa tertarik dan senang sehingga tercipta pembelajaran yang efektif dan efisien dalam mencapai tujuan pembelajaran.

\section{METODE PENELITIAN}

Penelitian ini mengambil lokasi di SD Negeri 27 Pekanbaru. Sesuai dengan Standar Kompetensi (SK) dan Kompetensi Dasar (KD) yang telah ditetapkan oleh pusat, maka penelitian ini akan dilaksanakan pada semester ganjil tahun ajaran 2020/2021. Penelitian ini dilaksanakan pada bulan Februari - Maret 2021. Objek dalam penelitian ini adalah seluruh siswa kelas V SD Negeri 27 Pekanbaru yang berjumlah 30 orang siswa.

Penelitian ini merupakan penelitian tindakan kelas yang bertujuan untuk meningkatkan kualitas atau mutu pendidikan. Arikunto (2006) menyatakan penelitian tindakan kelas adalah kajian sistematik dari 
upaya perbaikan pelaksanaan praktek pendidikan oleh sekolompok guru dengan melakukan tindakan-tindakan dalam pembelajaran, berdasarkan refleksi mereka mengenai hasil tindakan-tindakan tersebut. Wardani (2007) menyatakan bahwa penelitian tindakan kelas adalah penelitian yang dilakukan oleh guru di dalam kelasnya sendiri melalui refleksi diri dengan tujuan untuk memperbaiki kinerjanya sebagai guru, sehingga hasil belajar siswa meningkat. Tindakan kelas yang diberikan pada penelitian ini adalah penerapan metode pembelajaran discovery dalam rangka meningkatkan hasil belajar IPA siswa.

Menurut Arikunto (2006) setelah data terkumpul dari hasil pengumpulan data, perlu segera digarap oleh staf peneliti khususnya yang bertugas mengelola data. Dalam penelitian ini data yang dikumpul dikelompokkan dan diseleksi sesuai dengan permasalahan yang ingin dijawab, selanjutnya data tersebut diproses, dideskripsikan, dianalisis dan diinterprestasikan agar data yang diolah menjadi data yang akurat. Menganalisis data merupakan tahap pertama yang sangat penting dari seluruh rangkaian penelitian yang dilakukan, tahap inilah dapat menemukan jawaban terhadap pokok permasalahan. Keadaan yang ingin digambarkan adalah hasil belajar siswa di SD Negeri 27 Pekanbaru.

Aktivitas guru dan siswa dapat diketahui dengan menggunakan rumus :

$$
\mathrm{P}=\underline{\mathrm{F}} \times 100
$$

\section{$\mathrm{N}$}

Keterangan $: \mathrm{P}=$ angka persentase

$$
\begin{array}{cc}
\text { guru } & \mathrm{F}=\text { frekuensi aktivitas } \\
\text { guru } & \mathrm{N}=\text { total aktivitas } \\
\text { Hasil belajar } & \text { siswa dapat dihitung }
\end{array}
$$
dengan menggunakan rumus:

$$
\text { Skor }=\frac{\text { Skor yang diperoleh }}{\text { Skor maksimal }} \times 100 \%
$$

(KTSP, 2006)

Dalam penelitian ini siswa dikatakan berhasil apabila hasil yang didapatkan telah mencapai Kriteria Ketuntasan Minimum (KKM) yang telah ditentukan oleh sekolah yaitu adalah 70 untuk pelajaran IPA. Dalam penelitian ini siswa dikatakan tuntas jika telah mencapai Kriteria Ketuntasan Minimum (KKM) yang telah ditentukan oleh sekolah yaitu KKM IPA adalah 70 .

\section{HASIL DAN PEMBAHASAN}

Setelah penulis menganalisa hasil observasi awal hasil belajar sebelum tindakan, yang telah diketahui secara klasikal dalam mata pelajaran Ilmu Pengetahuan Alam masih tergolong rendah dengan ketuntasan klasikal $40 \%$ artinya secara keseluruhan hasil belajar Sosial siswa belum mencapai KKM yang telah di tetapkan yaitu 70. untuk lebih jelasnya dapat dilihat dalam tabel berikut : 

VOLUME 10 NOMOR 4 AGUSTUS 2021

ISSN : 2303-1514 | E-ISSN : 2598-5949

Tabel 1. Hasil Belajar Sebelum Tindakan

\begin{tabular}{|c|c|c|c|c|}
\hline \multicolumn{5}{|c|}{ SEBELUM TINDAKAN } \\
\hline No & Nama Siswa & Nilai & Keterangan & Tuntas/Tidak Tuntas \\
\hline 1 & Andika & 85 & Baik & $\begin{array}{l}\text { Tuntas } \\
\end{array}$ \\
\hline 2 & Angelina Stefani & 70 & Baik & Tuntas \\
\hline 3 & Anisa Tanzil & 65 & Baik & Tuntas \\
\hline 4 & Bima Aditya & 65 & Baik & Tuntas \\
\hline 5 & Chanya Nafasha & 65 & Baik & Tuntas \\
\hline 6 & Citra Hermila & 70 & Baik & Tuntas \\
\hline 7 & Dhewan Galih & 70 & Baik & Tuntas \\
\hline 8 & Dhirwani Ariski & 70 & Baik & Tuntas \\
\hline 9 & Eka Wahyudi & 70 & Baik & Tuntas \\
\hline 10 & Eko Saputra & 70 & Baik & Tuntas \\
\hline 11 & Farel Zaki & 70 & Baik & Tuntas \\
\hline 12 & Faris Muthi & 80 & Baik & Tuntas \\
\hline 13 & Jhoni Andreas & 75 & Sedang & Tidak Tuntas \\
\hline 14 & Jihan Rindra & 75 & Sedang & Tidak Tuntas \\
\hline 15 & M Ghuntur Khadafi & 75 & Sedang & Tidak Tuntas \\
\hline 16 & Mahrani & 65 & Sedang & Tidak Tuntas \\
\hline 17 & Meylani Gunaryo & 60 & Sedang & Tidak Tuntas \\
\hline 18 & M Ihsan Asajad & 60 & Sedang & Tidak Tuntas \\
\hline 19 & M Ridho & 60 & Sedang & Tidak Tuntas \\
\hline 20 & M Adham Alfaiz & 60 & Sedang & Tidak Tuntas \\
\hline 21 & M Naufal & 60 & Sedang & Tidak Tuntas \\
\hline 22 & M Prakarsa & 60 & Sedang & Tidak Tuntas \\
\hline 23 & Purnama Dian & 55 & Sedang & Tidak Tuntas \\
\hline 24 & Rival Andriawan & 55 & Sedang & Tidak Tuntas \\
\hline 25 & Romi Arnizon & 55 & Sedang & Tidak Tuntas \\
\hline 26 & Shelma & 50 & Sedang & Tidak Tuntas \\
\hline 27 & Sherly Putri & 50 & Sedang & Tidak Tuntas \\
\hline 28 & Siti Nazwa & 50 & Sedang & Tidak Tuntas \\
\hline 29 & Theo Ramadhan & 50 & Sedang & Tidak Tuntas \\
\hline 30 & Vika Nurva & 45 & Kurang & Tidak Tuntas \\
\hline & Jumlah & 1910 & & \\
\hline & Rata-rata & 63,7 & Sedang & Tidak Tuntas \\
\hline & Tuntas & 12 & & \\
\hline & Tidak Tuntas & 18 & & \\
\hline
\end{tabular}

Berdasarkan tabel 1 hasil belajar diperoleh persentase $40 \%$ artinya hasil belajar berada pada interval 40\%-55\% dengan kategori "Kurang Baik". Siswa yang tuntas hanya 12 orang dari 30 orang siswa, angka ini belum mencapai ketuntasan klasikal yang ditetapkan sekolah. Oleh karena itu penulis perlu dilakukan tindakan perbaikan yaitu pada siklus pertama dan penulis mengharapkan adanya peningkatan hasil belajar siswa setelah dilakukan siklus pertama, dalam penelitian ini penulis menerapkan metode pembelajaran discovery dalam pembelajaran daring.

\section{Siklus Pertama}

\section{Perencanaan Tindakan}

Dalam tahap perencanaan atau persiapan tindakan ini, dilaksanakan oleh guru dan observasi. Adapun langkah-langkah yang dilakukan adalah sebagai berikut:
1) Menyusun rencana pembelajaran

2) Menyiapkan lembar tugas siswa dan ulangan harian

3) Mempersiapkan lembar observasi aktivitas guru dan aktivitas siswa.

4) Meminta guru kelas atau teman sejawat untuk menjadi observer.

\section{Pelaksanaan Tindakan}

Dalam proses pelaksanaan pembelajaran melibatkan seluruh siswa kelas V SD Negeri 27 Pekanbaru. Pelaksanaan pembelajaran dilakukan berdasarkan Rencana Pelaksanaan Pembelajaran (RPP) yang telah dipersiapkan dan berpedoman pada silabus, dan kurikulum. Dalam pelaksanaan tindakan terdiri dari beberapa tahap yaitu: kegiatan awal atau pembukaan pembelajaran, yang dilaksanakan selama lebih kurang 10 menit. Kemudian dilanjutkan dengan kegiatan inti. Dalam kegiatan inti pelaksanaan pembelajaran berdasarkan strategi pembelajaran yang diteliti yaitu metode pembelajaran discovery dalam 
pembelajaran daring., yang dilaksanakan selama lebih kurang 50 menit, dan dilanjutkan dengan kegiatan akhir atau sebagai penutup pelajaran dilaksanakan selama lebih kurang 10 menit.

Observasi

Langkah observasi atau pengamatan dilaksanakan pada saat berlangsung pembelajaran IPA dengan menerapkan metode pembelajaran discovery dalam pembelajaran daring.. Observasi dilakukan untuk mengetahui aktivitas guru dan aktivitas siswa dalam proses pembelajaran yang diisi oleh observer yaitu guru kelas.

\section{Observasi Aktivitas Guru Siklus I}

Pelaksanaan observasi aktivitas guru adalah suatu gambaran pelaksanaan pembelajaran pada kegiatan awal, kegiatan inti, dan kegiatan akhir. Aktivitas guru terdiri dari 6 jenis aktivitas yang diobservasi sesuai dengan langkah-langkah metode pembelajaran discovery dalam pembelajaran daring.. Agar lebih jelas mengenai hasil observasi aktivitas guru dapat dilihat pada tabel sebagai berikut:

Tabel 2. Hasil Observasi Aktivitas Guru Siklus I

\begin{tabular}{|c|l|c|c|c|c|}
\hline No & \multicolumn{1}{|c|}{ Pelaksanaan Aktivitas } & \multicolumn{3}{|c|}{ Jumlah } & Skor \\
\hline 1 & Sangat sempurna & 0 & $\mathrm{x}$ & 5 & 0 \\
\hline 2 & Sempurna & 1 & $\mathrm{x}$ & 4 & 4 \\
\hline 3 & Kurang sempurna & 2 & $\mathrm{x}$ & 3 & 6 \\
\hline 4 & Tidak sempurna & 1 & $\mathrm{x}$ & 2 & 2 \\
\hline 5 & Tidak dilaksanakan & 0 & $\mathrm{x}$ & 1 & 0 \\
\hline Jumlah & & & & 12 \\
\hline Klasifikasi & \multicolumn{5}{|l|}{ Cukup sempurna } \\
\hline
\end{tabular}

Sumber: Data Olahan Penelitian Tahun 2021

Berdasarkan data pada tabel 2 di atas, dapat digambarkan. bahwa skor yang diperoleh guru dalam metode pemberian tugas dalam pembelajaran daring setelah dibandingkan dengan standar klasifikasi yang telah ditetapkan pada Bab III sebelumnya, aktivitas guru pada siklus pertama ini berada pada klasifikasi "cukup sempurna" dengan skor 12 yang berada pada interval $11-13$ atau dengan kategori cukup sempurna. Kemudian dari tabel IV.1 juga diketahui kekuatan dan kelemahan guru dalam metode pemberian tugas dalam pembelajaran daring antara lain:

1) Guru login pada aplikasi. Terkadang kendala yang sangat mempengaruhi kelnacaran dalam proses pembelajaran daring ini menyangkut kelancara akses jaringan internet. Sehingga perlu kesabaran dan waktu yang agak lama untuk menyesuaikannya. Pada tahap ini dilaksanakan oleh peneliti dengan kurang sempurna.
2) Guru menuju menu daftar untuk melihat hasil pekerjaan siswa, dalam pembelajaran daring yang dilakukan pada tahap ini Aplikasi tidak mampu berjalan baik dijaringan lokal atau Internet, dilaksanakan oleh peneliti dengan tidak sempurna

3) Guru melakukan pemeriksaan hasil pekerjaan siswa. dilaksanakan oleh peneliti dengan kurang sempurna.

4) Guru memberikan label pada setiap siswa yang memiliki kecocokan jawaban, mirip, atau serupa dalam bentuk persentase, memberi catatan komentar, dan memberi nilai dilaksanakan oleh peneliti dengan kurang sempurna.

\section{Observasi Aktivitas Siswa Siklus I}

Observasi aktivitas siswa dilakukan pada saat proses pembelajaran berlangsung yang sesuai dengan aktivitas guru. Adapun jumlah aktivitas siswa juga ada 6 jenis aktivitas relevan dengan aktivitas guru. Aktivitas siswa pada siklus pertama pertemuan 
pertama dapat dilihat pada tabel sebagai berikut:

Tabel 3. Hasil Observasi Aktivitas Siswa Siklus I

\begin{tabular}{|c|l|c|c|}
\hline No & \multicolumn{1}{|c|}{ Aktivitas siswa } & Skor & $\%$ \\
\hline 1 & $\begin{array}{l}\text { Siswa mempersiapkan } \\
\text { perangkat pembelajaran } \\
\text { dan login pada aplikasi }\end{array}$ & 19 & 63.3 \\
\hline 2 & $\begin{array}{l}\text { Siswa menuju menu daftar } \\
\text { untuk melihat soal tes } \\
\text { tertulis }\end{array}$ & 13 & 43.3 \\
\hline 3 & $\begin{array}{l}\text { Siswa selesai mengerjakan } \\
\text { tugas dan tetap terhubung } \\
\text { dengan aplikasi }\end{array}$ & 15 & 50 \\
\hline 4 & $\begin{array}{l}\text { Siswa mendengarkan } \\
\text { penjelasan guru dalam } \\
\text { memberikan kesimpulan }\end{array}$ & 14 & 46.7 \\
\hline Jumlah & \multicolumn{1}{|c|}{ Rendah } \\
\hline Rata-rata & \multicolumn{2}{|c|}{50.8} \\
\hline Klas ifikasi
\end{tabular}

Berdasarkan tabel 3 di atas, maka diketahui skor aktivitas siswa secara umum berklasifikasi "rendah", karena skor 61 berada pada interval $31-61$ dengan kategori rendah. Rata-rata siswa telah menunjukkan keaktifannya untuk mengikuti pelajaran, walaupun beberapa siswa belum menunjukkan tindak belajarnya secara maksimal karena masih terdapat siswa yang kurang aktif dalam proses pembelajaran, dan kurang mampu bekerjasama dengan baik dengan pasangannya. Hal tersebut terlihat pada aspek kedua (2) Siswa menuju menu daftar untuk melihat soal tes tertulis, memperoleh skor 13 atau sebesar $43.3 \%$, pada aspek ketiga (3) Siswa selesai mengerjakan tugas dan tetap terhubung dengan aplikasi memperoleh skor 15 atau sebesar $50 \%$, dan pada aspek keempat (4) yaitu Siswa mendengarkan penjelasan guru dalam memberikan kesimpulan memperoleh skor 14 atau sebesar $46.7 \%$

\section{Hasil Belajar Siswa pada Siklus I}

Berdasarkan hasil tes yang dilakukan terhadap siswa setelah proses pembelajaran dapat diketahui bahwa pada siklus I hasil belajar siswa masih tergolong "Cukup" dengan ketuntasan klasikal $72.7 \%$, pada interval $56 \%$ $75 \%$ Untuk lebih jelasnya dapat dilihat pada tabel 4 berikut ini: 
Tabel 4. Hasil Belajar Siswa Pada Siklus I

\begin{tabular}{|c|c|c|c|c|}
\hline No & Nama Siswa & Nilai & Keterangan & Tuntas/Tidak Tuntas \\
\hline 1 & Andika & 90 & Sangat Baik & Tuntas \\
\hline 2 & Angelina Stefani & 80 & Baik & Tuntas \\
\hline 3 & Anisa Tanzil & 80 & Baik & Tuntas \\
\hline 4 & Bima Aditya & 80 & Baik & Tuntas \\
\hline 5 & Chanya Nafasha & 75 & Baik & Tuntas \\
\hline 6 & Citra Hermila & 75 & Baik & Tuntas \\
\hline 7 & Dhewan Galih & 75 & Baik & Tuntas \\
\hline 8 & Dhirwani Ariski & 75 & Baik & Tuntas \\
\hline 9 & Eka Wahyudi & 75 & Baik & Tuntas \\
\hline 10 & Eko Saputra & 70 & Baik & Tuntas \\
\hline 11 & Farel Zaki & 70 & Baik & Tuntas \\
\hline 12 & Faris Muthi & 70 & Baik & Tuntas \\
\hline 13 & Jhoni Andreas & 70 & Baik & Tuntas \\
\hline 14 & Jihan Rindra & 70 & Baik & Tuntas \\
\hline 15 & M Ghuntur Khadafi & 70 & Baik & Tuntas \\
\hline 16 & Mahrani & 70 & Baik & Tuntas \\
\hline 17 & Meylani Gunaryo & 65 & Sedang & Tidak Tuntas \\
\hline 18 & M Ihsan Asajad & 65 & Sedang & Tidak Tuntas \\
\hline 19 & M Ridho & 65 & Sedang & Tidak Tuntas \\
\hline 20 & M Adham Alfaiz & 65 & Sedang & Tidak Tuntas \\
\hline 21 & M Naufal & 65 & Sedang & Tidak Tuntas \\
\hline 22 & M Prakarsa & 65 & Sedang & Tidak Tuntas \\
\hline 23 & Purnama Dian & 60 & Sedang & Tidak Tuntas \\
\hline 24 & Rival Andriawan & 60 & Sedang & Tidak Tuntas \\
\hline 25 & Romi Arnizon & 60 & Sedang & Tidak Tuntas \\
\hline 26 & \begin{tabular}{|l|} 
Shelma \\
\end{tabular} & 60 & Sedang & Tidak Tuntas \\
\hline 27 & Sherly Putri & 60 & Sedang & Tidak Tuntas \\
\hline 28 & Siti Nazwa & 60 & Sedang & Tidak Tuntas \\
\hline 29 & Theo Ramadhan & 60 & Sedang & Tidak Tuntas \\
\hline 30 & Vika Nurva & 55 & Sedang & Tidak Tuntas \\
\hline & $\begin{array}{c}\text { Jumlah } \\
\end{array}$ & 2060 & & \\
\hline & Rata-rata & 68.7 & Sedang & Tuntas \\
\hline & Tuntas & 16 & & \\
\hline & Tidak Tuntas & 14 & & \\
\hline & Ketuntasan & 53.3 & & \\
\hline
\end{tabular}

Berdasarkan tabel 4 di atas, dapat diketahui hasil belajar siswa pada mata pelajaran Ilmu Pengetahuan Alam setelah menerapkan metode pembelajaran discovery dalam pembelajaran daring. "Cukup" dengan nilai rata-rata siswa 68.7. Hal ini, menunjukkan bahwa ada peningkatan dari data sebelum tindakan ke siklus I.

\section{Refleksi}

Refleksi pada siklus pertama diperoleh berdasarkan hasil analisis data untuk tiap-tiap langkah pelaksanaan tindakan yang akan dideskripsikan peneliti pada tahap ini. Selanjutnya didiskusikan dengan observer, yang berperan sebagai observer yaitu guru kelas. Adapun refleksi siklus pertama adalah sebagai berikut:

1) Pada tahap perencanaan, guru telah melakukan persiapan pembelajaran dengan optimal. Kegiatan pembelajaran telah tergambar jelas pada lembaran RPP yang telah dipersiapkan dan berpedoman dengan silabus. Dengan demikian, pada siklus berikutnya guru tidak akan melakukan perubahan pada RPP, hanya saja lebih mengoptimalkan pelaksanaan pembelajaran sesuai dengan prosedur metode pembelajaran discovery dalam pembelajaran daring untuk mencapai tujuan secara maksimal.

2) Pada kegiatan inti pelaksanaan tindakan pada siklus pertama, guru belum melakukan aktivitas guru dengan baik. Untuk siklus II guru akan menjelaskan lebih rinci materi pembelajaran sesuai dengan tahapan metode pembelajaran discovery dalam pembelajaran daring. Tujuannya agar siswa memiliki pemahaman yang lebih mantap tentang metode serta materi pelajaran dan pada saat-saat tertentu siswa dapat mengemukakan pengetahuannya tersebut.

3) Pada hasil belajar siswa secara keseluruhan tergolong "Cukup" dengan rata-rata nilai siswa 68.7 dengan ketuntasan klasikal 53.3\%.

Berdasarkan hal di atas perlu diadakan perbaikan pada siklus berikutnya. Kekurangan 
pada siklus I dapat diperbaiki pada siklus II sehingga diperoleh peningkatan aktivitas guru, aktivitas siswa dan hasil belajar yang maksimal.

\section{Siklus Kedua}

Proses pembelajaran IPA pada siklus I belum memberikan hasil yang optimal untuk hasil belajar siswa, hal ini dapat dilihat dari hasil tes belajar pada siklus I yang menunjukkan tingkat ketuntasan hasil belajar siswa pada Siklus I sebesar 53.3\% yang masih di bawah persentase Kriteria Ketuntasan Minimal yaitu $80 \%$. Agar lebih mengoptimalkan hasil pembelajaran maka perlu dirancang suatu tindakan untuk dilaksanakan pada siklus kedua. Tindakan pada siklus kedua dimaksudkan untuk memperbaiki tindakan pada siklus I. Tindakan utama pada siklus I tetap dilaksanakan pada siklus II yaitu dengan penerapan metode pembelajaran discovery dalam pembelajaran daring.

\section{Perencanaan Tindakan}

Dalam tahap perencanaan atau persiapan tindakan ini, dilaksanakan oleh guru dan observasi. Adapun langkah-langkah yang dilakukan adalah sebagai berikut:

1) Menyusun rencana pelaksanaan pembelajaran

2) Menyiapkan lembar tugas siswa dan ulangan harian

3) Mempersiapkan lembar observasi aktivitas guru dan aktivitas siswa.

4) Meminta guru kelas atau teman sejawat untuk menjadi observer.

Pelaksanaan Tindakan
Proses pelaksanaan pembelajaran melibatkan seluruh siswa kelas V SD Negeri 27 Pekanbaru. Pelaksanaan pembelajaran dilakukan berdasarkan Rencana Pelaksanaan Pembelajaran (RPP) yang telah dipersiapkan dan berpedoman pada silabus, dan kurikulum. Dalam pelaksanaan tindakan terdiri dari beberapa tahap yaitu: kegiatan awal atau pembukaan pembelajaran, yang dilaksanakan selama lebih kurang 10 menit. Kemudian dilanjutkan dengan kegiatan inti. Dalam kegiatan inti pelaksanaan pembelajaran berdasarkan strategi pembelajaran yang diteliti yaitu metode pembelajaran discovery dalam pembelajaran daring, yang dilaksanakan selama lebih kurang 50 menit, dan dilanjutkan dengan kegiatan akhir atau sebagai penutup pelajaran dilaksanakan selama lebih kurang 10 menit.

\section{Observasi}

Langkah observasi atau pengamatan dilaksanakan pada saat berlangsung pembelajaran IPA dengan menerapkan Metode Pembelajaran Discovery. Observasi dilakukan untuk mengetahui aktivitas guru dan aktivitas siswa dalam proses pembelajaran yang diisi oleh observer yaitu guru kelas.

\section{Observasi Aktivitas Guru Siklus II}

Pelaksanaan observasi aktivitas guru adalah suatu gambaran pelaksanaan pembelajaran pada kegiatan awal, kegiatan inti, dan kegiatan akhir. Aktivitas guru terdiri dari 6 jenis aktivitas yang diobservasi sesuai dengan langkah-langkah metode pembelajaran discovery dalam pembelajaran daring. Agar lebih jelas mengenai hasil observasi aktivitas guru dapat dilihat pada tabel sebagai berikut:

Tabel 5. Hasil Observasi Aktivitas Guru

\begin{tabular}{|c|l|c|c|c|c|}
\hline No & \multicolumn{1}{|c|}{ Pelaks anaan Aktivitas } & \multicolumn{3}{|c|}{ Jumlah } & Skor \\
\hline 1 & Sangat sempurna & 2 & $\mathrm{x}$ & 5 & 10 \\
\hline 2 & Sempurna & 2 & $\mathrm{x}$ & 4 & 8 \\
\hline 3 & Kurang sempurna & $\mathrm{O}$ & $\mathrm{x}$ & 3 & 0 \\
\hline 4 & Tidak sempurna & $\mathrm{O}$ & $\mathrm{x}$ & 2 & 0 \\
\hline 5 & Tidak dilaks anakan & $\mathrm{O}$ & $\mathrm{x}$ & 1 & 0 \\
\hline Jumlah & \multicolumn{5}{|l|}{ Sangat Sempurna } \\
\hline
\end{tabular}

Sumber: Data Olahan Penelitian Tahun 2021 
Berdasarkan perolehan data dari tabel 5, bahwa skor yang diperoleh guru dalam metode pemberian tugas dalam pembelajaran daring setelah dibandingkan dengan standar klasifikasi yang telah ditetapkan pada Bab III sebelumnya, aktivitas guru pada siklus pertama ini berada pada klasifikasi "sangat sempurna" dengan skor 18 yang berada pada interval 18 20 atau dengan kategori cukup sempurna. Kemudian dari tabel 5 juga diketahui kelemahan guru dalam metode pemberian tugas dalam pembelajaran daring sudah dapat diperbaiki, sehingga kelemahan-kelemahan yang terdapat pada siklus I dapat teratasi dengan baik, yaitu yang paling utama adalah menggunakan akses layanan internet yang baik, sehingga dalam proses belajar mengajar dapat berlangsunga dengan baik dan lancar. Tindakan yang diambil antara lain :
1) Menggunakan aplikasi yang dapat membantu mengoreksi dan menilai hasil ujian dengan teliti, mudah, dan cepat.

2) Menggunakan aplikasi yang mampu berjalan baik di jaringan lokal atau Internet dan cocok dengan infrastruktur yang sudah ada di lingkungan tempat tinggal siswa.

3) Menggunakan aplikasi harus mudah diakses tanpa menginstal apapun kecuali software yang sudah terpasang di HP android

\section{Observasi Aktivitas Siswa Siklus II}

Kekuatan maupun kelemahan yang dilakukan guru yang telah dipaparkan sebelumnya diperkirakan akan mempengaruhi aktivitas siswa. Adapun mengenai aktivitas siswa dalam proses pembelajaran dengan penerapan metode pemberian tugas dalam pembelajaran daring dapat dilihat pada tabel berikut:

Tabel 6. Aktivitas Belajar Siswa pada Siklus II

\begin{tabular}{|c|l|c|c|}
\hline No & \multicolumn{1}{|c|}{ Aktivitas siswa } & Skor & $\%$ \\
\hline 1 & $\begin{array}{l}\text { Siswa mempersiapkan } \\
\text { perangkat pembelajaran } \\
\text { dan login pada aplikasi }\end{array}$ & 27 & 90 \\
\hline 2 & $\begin{array}{l}\text { Siswa menuju menu daftar } \\
\text { untuk melihat soal tes } \\
\text { tertulis }\end{array}$ & 26 & 86.7 \\
\hline 3 & $\begin{array}{l}\text { Siswa selesai mengerjakan } \\
\text { tugas dan tetap terhubung } \\
\text { dengan aplikasi }\end{array}$ & 24 & 80 \\
\hline 4 & $\begin{array}{l}\text { Siswa mendengarkan } \\
\text { penjelasan guru dalam } \\
\text { memberikan kesimpulan }\end{array}$ & 20 & 66.7 \\
\hline Jumlah & 97 & 80.8 \\
\hline Rata-rata & \multicolumn{2}{|c|}{ Sangat ting } \\
\hline Klas ifikasi
\end{tabular}

Sumber: Data Hasil Observasi, 2020

Berdasarkan tabel 6 maka diketahui skor aktivitas siswa secara umum berklasifikasi "sangat tinggi", karena skor 97 berada pada interval 93 - 120 dengan kategori sangat tinggi. Rata-rata siswa telah menunjukkan keaktifannya untuk mengikuti pelajaran, adapun indikator aktivitas siswa pada siklus kedua yang dijumpai oleh peneliti, tidak terlihat adanya kelemahan, maka pada siklus kedua ini telah terjadi peningkatan yang signifikan. Hal tersebut terlihat pada aspek pertama, yaitu Siswa mempersiapkan perangkat pembelajaran dan login pada aplikasi pada siklus I memperoleh persentase sebesar $63.3 \%$ atau 19 orang siswa meningkat menjadi $90 \%$ atau 27 orang siswa pada siklus II. Pada aspek kedua (2) Siswa menuju menu daftar untuk melihat soal tes tertulis pada siklus I memperoleh skor 13 atau sebesar 43.3\% meningkat menjadi $86.7 \%$ atau 26 orang siswa pada siklus II. Pada aspek ketiga (3) Siswa selesai mengerjakan tugas dan tetap terhubung dengan aplikasi pada siklus I memperoleh skor 15 atau sebesar 50\% 
ISSN : 2303-1514 | E-ISSN : 2598-5949

DOI : http://dx.doi.org/10.33578/jpfkip.v10i4.8452

https://primary.ejournal.unri.ac.id/index.php/JPFKIP

meningkat menjadi $80 \%$ atau 24 orang siswa pada siklus II, dan pada aspek keempat (4) yaitu Siswa mendengarkan penjelasan guru dalam memberikan kesimpulan, pada siklus I memperoleh skor 14 atau sebesar $46.7 \%$ meningkat menjadi $66.7 \%$ atau 20 orang siswa pada siklus II. Dengan kata lain terjadi peningkatan pada aspek pertama sebanyak 8 orang siswa atau $26.7 \%$, pada aspek kedua sebanyak 13 orang siswa atau $43.3 \%$, pada aspek ketiga sebanyak 9 orang siswa atau 30\%, dan pada aspek keempat sebanyak 6 orang siswa atau $20 \%$.

\section{Hasil Belajar Siswa pada Siklus II}

Berdasarkan hasil tes yang dilakukan terhadap siswa setelah proses pembelajaran dapat diketahui bahwa pada siklus II hasil belajar siswa tergolong "Baik" dengan persentase $86.7 \%$, pada interval $76 \%$ - $100 \%$ Untuk lebih jelasnya dapat dilihat pada tabel 7 berikut ini:

Tabel 7. Hasil Belajar Siswa Pada Siklus II

\begin{tabular}{|c|c|c|c|c|}
\hline No & $\begin{array}{l}\text { Nama Siswa } \\
\end{array}$ & Nilai & Keterangan & Tuntas/Tidak Tuntas \\
\hline $\mathbf{1}$ & Andika & 90 & Sangat Baik & Tuntas \\
\hline 2 & Angelina Stefani & 80 & Sangat Baik & Tuntas \\
\hline 3 & Anisa Tanzil & 80 & Sangat Baik & Tuntas \\
\hline 4 & Bima Aditya & 80 & Sangat Baik & Tuntas \\
\hline 5 & Chanya Nafasha & 80 & Sangat Baik & Tuntas \\
\hline 6 & Citra Hermila & 90 & Sangat Baik & Tuntas \\
\hline 7 & Dhewan Galih & 85 & Baik & Tuntas \\
\hline 8 & Dhirwani Ariski & 85 & Baik & Tuntas \\
\hline 9 & Eka Wahyudi & 85 & Baik & Tuntas \\
\hline 10 & Eko Saputra & 85 & Baik & Tuntas \\
\hline 11 & Farel Zaki & 80 & Baik & Tuntas \\
\hline 12 & Faris Muthi & 90 & Baik & Tuntas \\
\hline 13 & Jhoni Andreas & 90 & Baik & Tuntas \\
\hline 14 & Jihan Rindra & 90 & Baik & Tuntas \\
\hline 15 & M Ghuntur Khadafi & 90 & Baik & Tuntas \\
\hline 16 & Mahrani & 80 & Baik & Tuntas \\
\hline 17 & Meylani Gunaryo & 80 & Baik & Tuntas \\
\hline 18 & M Ihsan Asajad & 75 & Baik & Tuntas \\
\hline 19 & M Ridho & 75 & Baik & Tuntas \\
\hline 20 & M Adham Alfaiz & 75 & Baik & Tuntas \\
\hline 21 & M Naufal & 75 & Baik & Tuntas \\
\hline 22 & M Prakarsa & 75 & Baik & Tuntas \\
\hline 23 & Purnama Dian & 70 & Baik & Tuntas \\
\hline 24 & Rival Andriawan & 70 & Baik & Tuntas \\
\hline 25 & Romi Arnizon & 70 & Baik & Tuntas \\
\hline 26 & Shelma & 70 & Baik & Tuntas \\
\hline 27 & Sherly Putri & 65 & Sedang & Tidak Tuntas \\
\hline 28 & Siti Nazwa & 65 & Sedang & Tidak Tuntas \\
\hline 29 & Theo Ramadhan & 60 & Sedang & Tidak Tuntas \\
\hline 30 & Vika Nurva & 60 & Sedang & Tidak Tuntas \\
\hline & Jumlah & 2345 & & \\
\hline & Rata-rata & 78.2 & Baik & Tuntas \\
\hline & Tuntas & 26 & & \\
\hline & Tidak Tuntas & 4 & & \\
\hline & Ketuntasan & 86.7 & & \\
\hline
\end{tabular}

Sumber: Data Olahan Penelitian Tahun 2021

Berdasarkan tabel 7 di atas, dapat diketahui hasil belajar siswa pada mata pelajaran Ilmu Pengetahuan Alam setelah penerapan metode pembelajaran discovery dalam pembelajaran daring tergolong "Baik" dengan nilai rata-rata 78.2 dengan ketuntasan klasikal $86.7 \%$. Hal ini, menunjukkan bahwa ada peningkatan dari data sebelum tindakan ke Siklus I dan dari Siklus I ke Siklus II.

\section{Refleksi}

Jika diperhatikan hasil siklus kedua, hasil belajar yang ditunjukkan oleh siswa mengalami peningkatan dibanding dengan sebelum tindakan dan siklus pertama. Artinya tindakan yang diberikan guru pada siklus kedua berdampak lebih baik dari tindakan pada siklus sebelumnya. Hal ini memberikan gambaran bahwa dalam mencapai hasil belajar yang maksimal, siswa membutuhkan waktu dan proses untuk memahami materi pelajaran tersebut. Pada awalnya siswa perlu dibimbing 
secara secara berkesinambungan, namun dalam prosesnya siswa siswa diberikan kesempatan untuk bisa menemukannya tanpa bantuan atau bimbingan guru.

Alokasi waktu yang diberikan kepada siswa juga berdampak positif terhadap hasil belajar siswa hal ini terbukti dari dua kali pertemuan pada setiap siklusnya siswa mampu belajar dengan baik dengan pencapaian hasil belajar secara keseluruhan dengan kategori "Baik", jika dibandingkan dengan nilai siswa sebelum tindakan dan siklus I.

Faktor yang mempengaruhi kenaikan pada siklus ini diantaranya managemen kelas yang baik mempengaruhi hasil belajar semakin meningkat terlihat proses dalam belajar semakin terarah dan berdasarkan langkahlangkah metode yang diterapkan. Managemen kelas yang baik dapat dilihat dari proses belajarnya yang semakin aktif dan menerapkan metode, hal ini memunculkan kedewasaan dalam belajar. Hal ini membuktikan bahwa strategi peta konsep sapat mening.katkan hasil belajar siswa.

\section{Pembahasan}

Dari hasil penelitian pada siklus I menunjukkan bahwa hasil belajar belum mencapai indikator yang ditetapkan. Hal ini disebabkan pengelolaan pembelajaran pada siklus I yang dirasa belum optimal seperti dijelaskan dalam siklus I. Aktivitas guru pada siklus kedua ini telah berada pada klasifikasi "sangat sempurna" dengan skor 19 pada interval $18-20$ yang apabila dibandingkan dengan aktivitas guru pada siklus pertama berada pada klasifikasi "cukup sempurna" dengan skor 12 yang berada pada interval 11 13. Diketahui juga kelemahan-kelemahan guru dalam penerapan metode pemberian tugas dalam pembelajaran daring pada siklus pertama telah diperbaiki pada siklus kedua.

Aktivitas siswa pada siklus II secara umum berklasifikasi "sangat tinggi", karena skor 97 berada pada interval 93 - 120 dengan kategori sangat tinggi. Rata-rata siswa telah menunjukkan keaktifannya untuk mengikuti pelajaran, bila dibandingkan aktivitas siswa siklus pertama secara umum berklasifikasi "rendah", karena skor 61 berada pada interval 31 - 61 dengan kategori rendah. Peningkatan aktivitas siswa terlihat pada semua aspek. Walaupun pada siklus I sebagian besar siswa telah menunjukkan aktivitasnya untuk belajar namun masih terdapat siswa yang kurang perhatian dalam belajarnya. Hal ini mengindikasikan bahwa proses pembelajaran yang dibawakan peneliti masih perlu perencanaan yang lebih baik. Dengan memperhatikan kelemahan maupun kekuatan yang telah teridentifikasi pada siklus I dan digunakan sebagai dasar perbaikan untuk mencapai keberhasilan pada siklus II.

Berdasarkan hasil observasi sebelum tindakan hasil belajar siswa diperoleh nilai rata-rata 63.7 dengan ketuntasan klasikal $40 \%$ berada pada intercal 40\%-55\% dengan kategori "Kurang Baik". Kemudian berdasarkan hasil tes pada siklus pertama yang menunjukkan bahwa hasil belajar siswa mencapai nilai ratarata 68.7 dengan ketuntasan klasikal $53.3 \%$ berada pada interval $40 \%-55 \%$ dengan kategori "Kurang Baik". Sedangkan pada siklus II terjadi peningkatan dengan perolehan nilai rata-rata siswa 78.2 dengan ketuntasan klasikal $86.7 \%$ berada pada interval $76 \%$ $100 \%$ dengan kategori "Baik". Peningkatan hasil belajar siswa pada data awal, Siklus I dan Siklus II secara jelas dapat dilihat pada tabel berikut ini:

Tabel 9. Rekapitulasi Hasil Belajar Siswa

\begin{tabular}{|c|c|c|}
\hline No & Hasil Belajar & Ketuntasan Klasikal \\
\hline 1 & Sebelum Tindakan & $40 \%$ \\
\hline 2 & Siklus I & $53.30 \%$ \\
\hline 3 & Siklus II & $86.70 \%$ \\
\hline
\end{tabular}

Sumber: Data Olahan Penelitian Tahun 2021 
Berdasarkan tabel 9, dapat diketahui pada data awal atau sebelum tindakan hasil belajar siswa secara klasikal belum mencapai indikator keberhasilan yang ditetapkan yaitu mencapai angka $80 \%$, begitu juga pada siklus I secara klasikal siswa belum mencapai angka indikator keberhasilan yang ditetapkan, namun secara individu hasil belajar siswa meningkat dari 12 orang siswa yang tuntas sebelum tindakan meningkat menjadi 14 orang siswa yang tuntas pada siklus I. Pada siklus II jumlah siswa yang tuntas menjadi 26 dari 30 orang siswa dengan nilai rata-rata individu mencapai 78.2 dengan ketuntasan $86.7 \%$. Secara klasikal hasil belajar siswa telah mencapai indikator keberhasilan yaitu $80 \%$.
Keberhasilan ini dipengaruhi karena metode pembelajaran discovery dalam pembelajaran daring, karena metode ini merupakan model mengajar yang berusaha meletakkan dasar dan mengembangkan cara berpikir ilmiah, siswa betul-betul ditempatkan sebagai subjek yang belajar, peranan guru dalam model pembelajaran discovery adalah pembimbing belajar dan fasilitator belajar. Tugas utama guru adalah memilih masalah yang perlu dilontarkan kepada kelas untuk dipecahkan oleh siswa sendiri. Tugas berikutnya dari guru adalah menyediakan sumber belajar bagi siswa dalam rangka pemecahan masalah. Perbandingan hasil belajar siswa pada data awal, siklus I dan II juga dapat dilihat pada gambar historam ini:

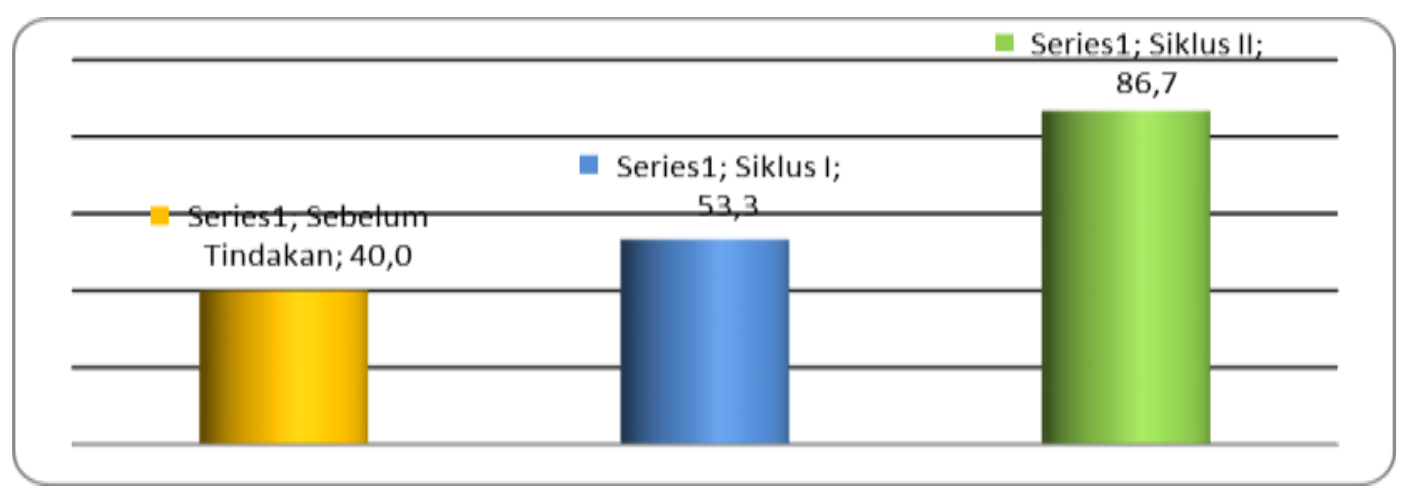

\section{Gambar 1. Grafik Hasil Belajar Siswa}

Berdasarkan pembahasan, maka dapat disimpulkan bahwa kelemahan-kelemahan penerapan Metode Pembelajaran Discovery pada data awal dan siklus I, dapat diperbaiki pada siklus II dan dapat meningkatkan hasil belajar siswa melalui perbaikan proses penerapan Metode Pembelajaran Discovery pada siklus II tersebut, rata-rata hasil belajar siswa mencapai 78.2, dengan ketuntasan klasikal $86.7 \%$.

\section{KESIMPULAN DAN SARAN}

Berdasarkan hasil analisis dan pembahasan dapat disimpulkan bahwa penerapan metode pembelajaran discovery dalam pembelajaran daring dapat meningkatkan hasil belajar pada pelajaran IPA siswa kelas V SD Negeri 27 Pekanbaru. Keberhasilan ini dibuktikan dengan adanya peningkatan hasil belajar sebelum dilakukan tindakan ke siklus I dan ke siklus II. Sebelum dilakukan tindakan hasil belajar siswa tergolong "Kurang Baik" dengan persentase $40 \%$, terjadi peningkatan pada siklus I menjadi $53.3 \%$ dengan kriteria "Kurang Baik". Sedangkan hasil belajar siswa pada siklus II juga terjadi peningkatan mencapai $86.7 \%$ dengan kategori "Baik", hal ini membuktikan bahwa dengan penerapan Metode Pembelajaran Discovery dalam pembelajaran daring dapat meningkatkan hasil belajar IPA siswa kelas V SD Negeri 27 Pekanbaru. 
Berdasarkan kesimpulan dan pembahasan hasil penelitian yang berkaitan dengan penerapan metode pembelajaran discovery dalam pembelajaran daring yang telah dilaksanakan, peneliti mengajukan beberapa saran yaitu:

1. Penerapan metode pembelajaran discovery, dapat digunakan oleh guru pada tingkat kelas yang lebih tinggi.

2. Diharapkan dengan adanya penelitian ini dapat menjadi pertimbangan bagi guru dalam memilih strategi pembelajaran dalam meningkatkan hasil belajar siswa

3. Guru perlu melakukan upaya-upaya guna mempertahankan hasil belajar siswa demi tercapainya hasil belajar yang optimal dengan menerapkan metode pembelajaran yang bervariasi

4. Kepada kepala sekolah perlu memantau dan membina terhadap dampak kegiatan Penelitian Tindakan Kelas (PTK), sebagai bahan penilaian kemajuan yang telah dicapai, sehingga apa yang ditemukan pada PTK dapat diimplementasikan dalam pelaksanaan pembelajaran di sekolah

5. Kepada peneliti selanjutnya dalam pengembangan ilmu pengetahuan diharapkan hendaknya dapat menerapkan metode pembelajaran discovery dalam pembelajaran daring pada mata pelajaran lainnya.

\section{DAFTAR PUSTAKA}

Asran, A. (2021). Improving Students' Reading Ability through Picture Media during the Pandemic Period. Jurnal PAJAR (Pendidikan dan Pengajaran), 5(3), 741-746. DOI : http://dx.doi.org/10.33578/pjr.v5i3.8 401.

Azuar, A. (2021). The Implementation of Discussion Method through Zoom Meeting for PKN Learning during the Pandemic Period. Jurnal PAJAR (Pendidikan dan Pengajaran), 5(3), 703-709. http://dx.doi.org/10.33578/pjr.v5i3.8 $\underline{396 .}$.

Arikunto, S. (2006). Prosedur Penelitian Suatu Pendekatan Praktek. Jakarta: Rineka Cipta.

Azimah, R., \& Kurniaman, O. (2019). Implementasi Gerakan Literasi Sekolah dalam Pembelajaran di Kelas Tinggi. Jurnal PAJAR (Pendidikan dan Pengajaran), 3(4), 934-947.

DOI: http://dx.doi.org/10.33578/pjr.v3i4.7 $\underline{567 .}$

Dimyati dan Mudjiono. (2008). Belajar dan Pembelajaran. Jakarta: Rineka Cipta.

Dewi. (2007). Sistem Pembelajaran Daring. Jakarta: Rineka Cipta.

Gustiana, G. (2021). A Training by Using Google Meet for Elementary School Teachers. Jurnal PAJAR (Pendidikan dan Pengajaran), 5(3), 772-777. DOI

http://dx.doi.org/10.33578/pjr.v5i3.8 393.

Kurniaman, O., \& Huda, M. N. (2018). Penerapan Strategi Bercerita Untuk Meningkatkan Keterampilan Menyimak Siswa Kelas III SD Muhamadiyah 6 Pekanbaru. Primary: Jurnal Pendidikan Guru Sekolah Dasar, 7 (2), 249-255.

Mulyasa. (2007). Standar Kompetensi dan Sertifikasinya. Bandung: Rosda Karya.

Nur, F. (2021). Students' Mathematics Learning Outcomes through Online Learning. Primary: Jurnal Pendidikan Guru Sekolah Dasar, 10 (3), 282-289. DOI:

http://dx.doi.org/10.33578/jpfkip.v10 i3.8248.

Purwanto, N. (2007). Prinsip-prinsip dan Teknik Evaluasi Pengajaran. Bandung: Remaja Rosdakarya.

Roestiyah. (2001). Strategi Belajar Mengajar. Jakarta. Rineka Cipta. 
ISSN : 2303-1514 | E-ISSN : 2598-5949

Ro'ifah. R., Pratiwi. I. A., \& Ismaya, E. A. (2021). The Role Of Teacher In Online Learning To Rise The Students Interest In Elementary School Of Kedungsari Village. Primary: Jurnal Pendidikan Guru Sekolah Dasar, 10 (2), 473-484. DOI: http://dx.doi.org/10.33578/jpfkip.v10 i2.8125

Slameto. (2003). Belajar Dan Faktor-Faktor Yang Mempengaruhinya. Jakarta: Rineka cipta

Sugiarto, S. (2021). Analyzing Teachers' Ability in Implementing Online Learning at SDN 005 Kempas Jaya. Jurnal PAJAR (Pendidikan dan
Pengajaran), 5(3), 797-803. DOI : http://dx.doi.org/10.33578/pjr.v5i3.8 411.

Sardiman. (2008). Interaksi dan Hasil belajar Mengajar. Jakarta: PT Raja.

Syah, M. (2007). Psikologi Pendidkan Dengan Pendekatan Baru. Bandung: Remaja Rosda Karya.

Wardani. (2007). Penelitian Tindakan Kelas. Jakarta: UT.

Yuliana, N. (2018). Penggunaan Model Pembelajaran Discovery Learning Dalam Peningkatan Hasil Belajar Siswa Di Sekolah Dasar. Jurnal Ilmiah Pendidikan dan Pembelajaran, 2(1), 21-28. 